\title{
THE NATURE OF STILL'S DISEASE WITH REPORT OF A CASE
}

\author{
BY \\ F. A. LANGLEY, M.Sc., M.B., Ch.B. \\ (From the Department of Pathology, Victoria University of Manchester)
}

The following case of Still's disease is reported because of the unusually full pathological data that were available and because of the light these throw on the nature of the disease.

Still's disease is defined clinically as a form of chronic arthritis with swelling of the lymph glands and spleen. The swellings of the joints and lymph glands are usually multiple and symmetrical. The disease generally starts before the second dentition (Still, 1897; Simonetti, 1930) but sometimes occurs in adults (Strauss, 1926; Micheli and Gamna, 1928). The onset is usually insidious but sometimes acute and often accompanied by fever. The course is chronic; intermissions of fever may be associated with regression of the swellings of the joints, glands and spleen but both fever and the other changes often recur (Still, 1897; Simonetti, 1930; Bini, 1935). To the three cardinal signs may be added, in order of frequency: anaemia, muscular atrophy, cachexia, pericarditis, pleurisy, exophthalmos (Bini, 1935) and exanthemata (Simonetti, 1930).

\section{Case report}

S. W., a boy aged four years, was admitted to St. Mary's Hospital, Manchester, in April, 1943. The course of the disease was as follows: November, 1942 , the knees were stiff and painful but the patient walked fairly well. April, 1943, there was a fusiform swelling of knees, elbows, metacarpophalangeal and interphalangeal joints of the hands; these were not tender nor were the joints fixed. Muscle wasting was severe and there was loss of weight. May, 1943, a bout of intermittent pyrexia lasting a fortnight, temperature ranging from $100^{\circ}$ to $106^{\circ} \mathrm{F}$. The joints were painful. Towards the end of the attack and following it for about a week there was a papular eruption all over the body.

June, 1943, there was a brief recrudescence of rash in another bout of pyrexia.

August, 1943, an enlarged gland was found in the right groin, and about a week later many small glands were palpable in neck and axillae.

September, 1943, the left hip was almost fixed and the right was adducted and flexed. Both knees were held in $60^{\circ}$ flexion, reducible to $20^{\circ}$; there seemed to be an effusion. There was a valgus deformity of the right ankle and a flexion deformity and swelling of both wrists.

November, 1943, the spleen was felt for the first time about the middle of the month; bronchopneumonia occurred at the end of the month.

December 1, 1943, pericarditis was found.

December 7, 1943, the child died.

Laboratory findings. The following are representative blood counts:

12.4.43. Hb. 62 per cent. Red blood cells, 3.6 million. White blood cells, 6900/c.mm.

16.8.43. Hb. 72 per cent. Red blood cells, $4 \cdot 5$ million. White blood cells, 7200/c.mm.

8.10.43. Hb. 70 per cent. Red blood cells, $5 \cdot 2$ million. White blood cells, 6900/c.mm.

BACTERIOLOGICAL EXAMINATION of the faeces, nasopharynx and tonsils showed no significant abnormality.

VON PIRQUeT's TEST was negative.

RADIOLOGICAL EXAMINATION of the joints showed no significant change.

Summary of the relevant post-mortem findings. The lymph glands at the bifurcation of the trachea, along the splenic vessels and in the mesentery were enlarged $(1.5 \times 0.75 \mathrm{~cm}$.$) , and those in the popliteal$ fossa were enlarged to a less extent. They were discrete, firm and elastic and had a uniform grey appearance on section. There was a fibrinous pericarditis with a few recent fibrous adhesions, a fibrinous pleurisy on the right side and bilateral bronchopneumonia. The liver (840 gm.) was moderately fatty. The spleen (160 gm.) was enlarged for the age and there was a fibrinous exudate on the surface.

The left knee was excised. Its capsule was thickened. The infra-patellar pad of fat and both surfaces of the semilunar cartilages were hyperaemic. A number of pits were present in the cartilage of the upper end of the tibia under the semilunar cartilages (fig. 1). On the femoral condyles were similar but shallower pits; these were pink.

The other organs showed no significant abnormality.

Histological findings. KNEE. The synovial membrane reflected on to the articular cartilage was infiltrated with lymphocytes and the lymph channels were dilated. The underlying cartilage was eroded. The cartilage in the centre of the joint surface had a fibrillar structure for a depth of $\frac{1}{2}-1 \mathrm{~mm}$. The pits (fig. 2) were partly filled with a loose reticular tissue composed of argyrophilic fibrils, stellate cells and lymphocytes, which was covered by a layer of flattened cells. The fibrils ran in all directions but at the margins tended to lie at right angles to the surrounding cartilage (fig. 3). A few of them could 


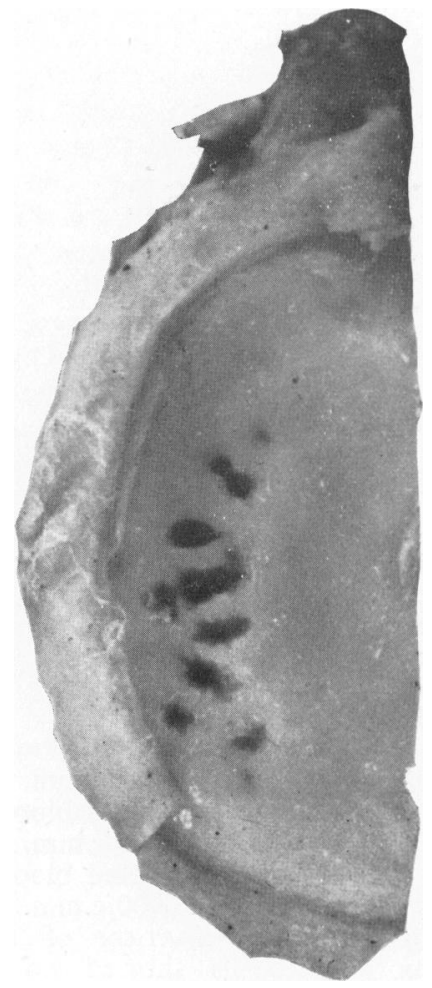

FIG. 1.-Part of the head of the left tibia showing the pits which underlay the semilunar cartilage $(\times 2)$.

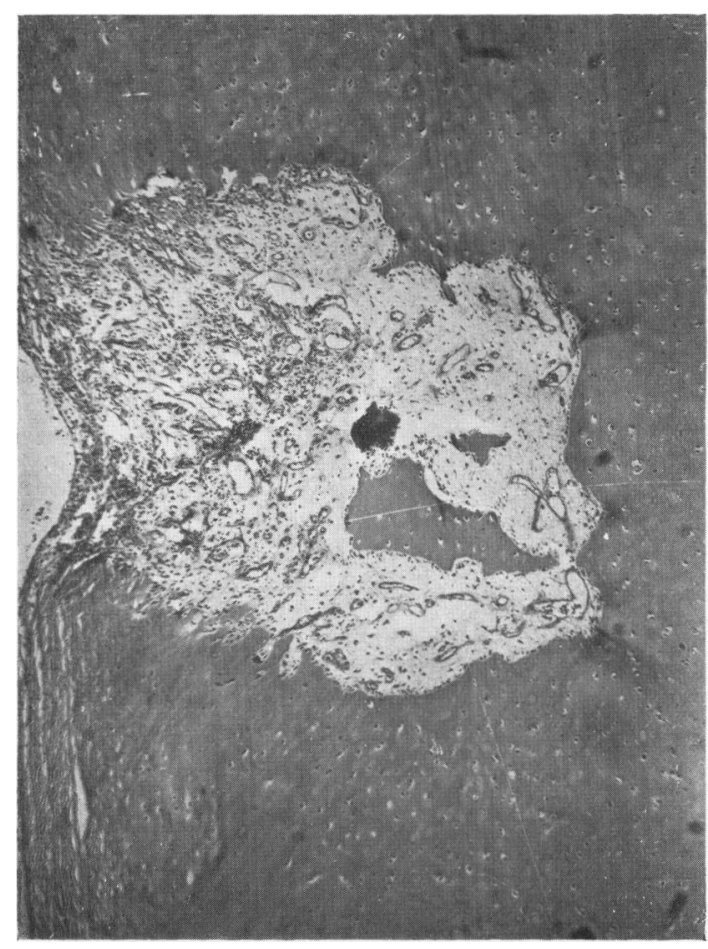

FIG. 2.-Vertical section of a pit on the surface of the femoral condyle $(H$. and $E . \times 35)$.

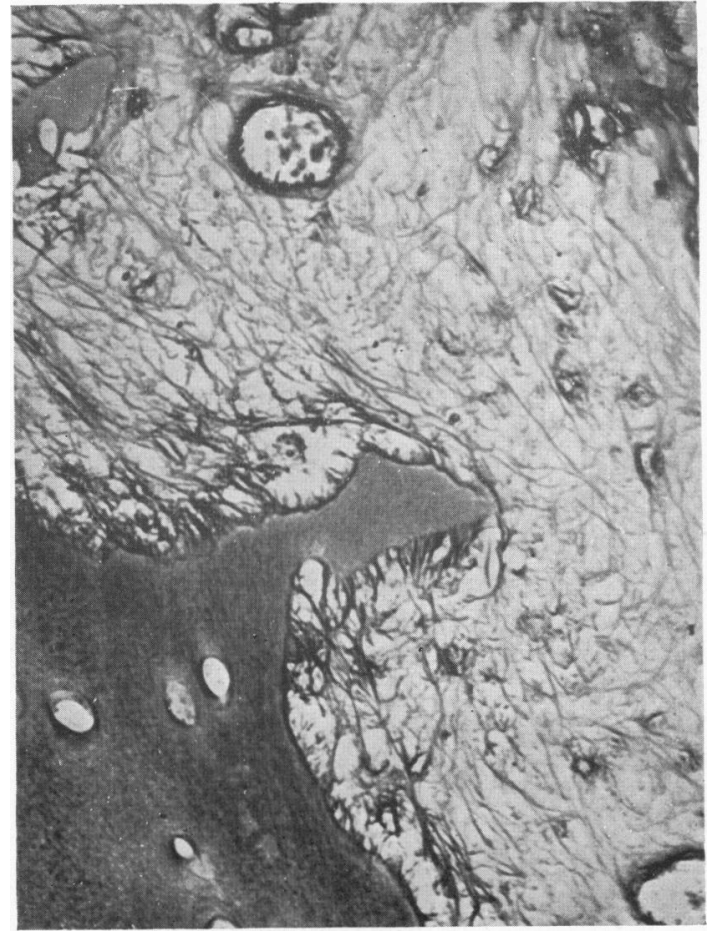

Fig. 3.-The edge of a pit showing the argyrophil fibrils at right angles to the cartilage (silver impregnation $\times 300)$.

be traced into the hyaline cartilage. Many of the stellate cells contained fat globules, in this respect and in morphology closely resembling the cartilage cells (fig. 4). There were also spaces lined by swollen endothelium, some containing red cells whilst others, probably lymph vessels, were filled with fat. Cavities similar to these pits were present in the depth of the cartilage; these were filled with a similar reticular tissue which, however, contained no lymphocytes. Some of these cavities communicated with the ossification centre. One of the superficial pits (fig. 2) showed a detached island of cartilage.

On the surfaces of the infra-patellar pads of fat were scattered deposits of fibrin, some partially organized. The underlying tissue showed a widespread chronic inflammatory reaction. The infiltration was mostly lymphocytic but a few plasma cells and polymorphs were present and a moderate number of macrophages. In some places the leucocytes had a perivascular distribution.

SPLEEN. The pulp was packed with polymorphs as in the so-called septic spleen. The sinuses were conspicuous owing to swelling of the littoral cells. The argyrophilic reticulum was conspicuous but van Gieson's stain showed no increase in collagen. There was a hyaline thickening of the intima of most of the small arteries. The appearances were those of early 'fibro-adénie' as seen in splenic anaemia.

THE LYMPH GLANDS varied in appearance. (1) The abdominal glands were congested; the sinuses were dilated and loosely filled with lymphocytes and histiocytes, some of the littoral cells were swollen. The follicles were poorly defined and only a few 


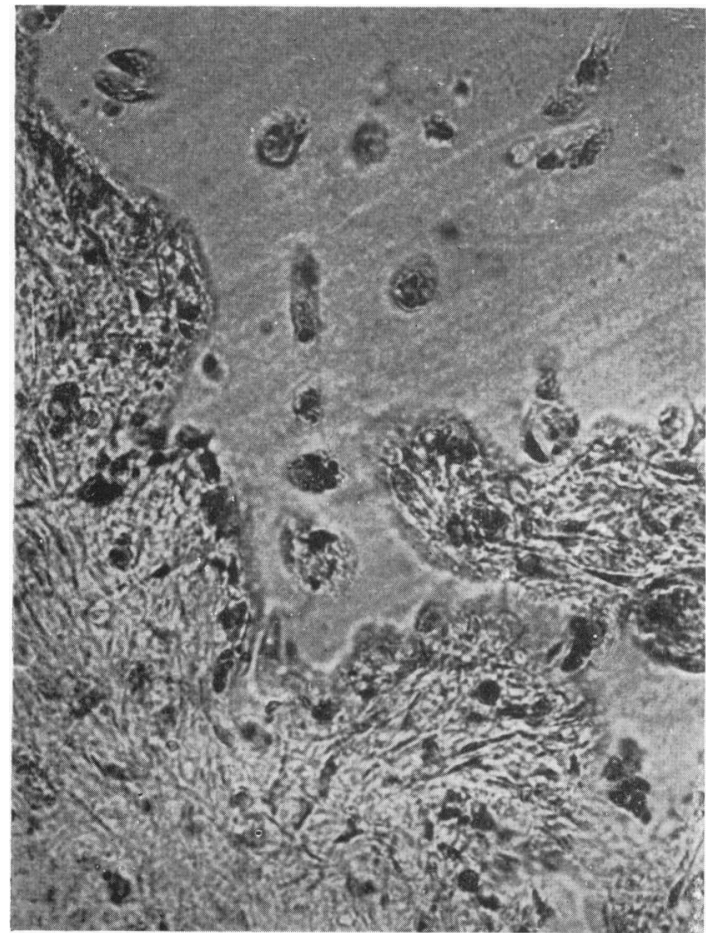

FIG. 4.-The edge of a cavity in the cartilage showing the fat droplets (black) in the cells of the cartilage and cavity (Sudan IV and Haemalum $\times 300$ ).

had 'germinative' centres. In the medulla were a few groups of large cells with pale voluminous, oval or reniform nuclei with one or two nucleoli. Their cytoplasm stained faintly and was ill-defined with projecting fingers. These were either reticulum cells or undifferentiated mesenchymal cells. Mitoses were uncommon. These groups of cells were not present in all glands. Associated with them were histiocytes, some showing erythrophagocytosis. (2) The popliteal glands were similar to the abdominal ones except that there was much fibrosis extending from the hilum into the centre and some of the groups or voluminous cells appeared to surround vascular spaces and sinuses.

Microscopic examination of the pericardium, myocardium, lungs, liver, and kidneys confirmed the naked eye appearances. The bone marrow appeared normal. Nowhere were Aschoff nodules or tubercle bacilli found.

\section{Discussion}

Morbid anatomy. The anatomical changes reported by previous authors are summarized in the table.

THE JOINTS may show chronic inflammation of the soft tissues (Stoye, 1926; Levi, 1935) but Bini (1935) found no change. Only one previous case showed pits in the articular cartilage (Still, 1897) and no histological description was given. The pits in the present case were probably produced by a degeneration of the interstitial substance of the cartilage. This is suggested by the fragments of cartilage lying free in the reticular tissue of the pits (fig. 2) and confirmed by the similarity of the stellate cells to the cells of the surrounding cartilage and the arrangement of many of the argyrophil fibrils. These fibrils were at right angles to the margins of the cavity, as if they were a continuation of the argyrophil fibrils of the cartilage itself, described by Bloom (1943), and not a new formation. The free fat in the endothelial lined spaces is probably a product of degeneration.

LYMPH GLANDS have been examined more often than any other organs, since biopsy of these is easy. The descriptions vary. This may partly be due to the following factors, viz. (1) the changes in the glands are progressive (Simonetti, 1930); (2) the size of the glands, and hence probably the histological appearances, vary with the phase of the disease (Simonetti, 1930; Benedettelli, 1934); (3) although the enlargement of the glands is general, it is most marked near the affected joints (Still, 1897; Benedettelli, 1934). In the present case the changes in the popliteal glands were more advanced than in the abdominal ones. In Benedettelli's case the wrists were particularly affected and the changes in the epitrochlear glands more marked than in the axillary and inguinal glands. Sinus catarrh and the formation of germ follicles are the most usual changes (Micheli and Gamna, 1928; Simonetti, 1930; Benedettelli, 1934; Bini, 1935; Oggioni and Toldo, 1935; Levi, 1935 and 1938). Both changes are usually present in the same gland but sometimes they occur independently of one another. Such changes are commonly seen in lymph nodes draining sites of pyogenic infection but, according to Robb-Smith (1938), they are seldom found in generalized lymph node enlargement. Levi $(1935,1938)$ found ectopic haematopoiesis in both his cases. Maximow (1907) states that Dominici found ectopic haematopoiesis in glands in chronic infections and Lang (1935) gives a list of infections in which myeloid metaplasia has been found. The fibrosis found in the glands in cases of long duration (Oggioni and Toldo, 1935; Levi, 1938; and in the present case) suggest a chronic inflammatory reaction.

Thickening of the capsule of lymph glands has been reported by Strauss (1926), Oggioni and Toldo 1935) and Levi (1935); Levi's case also showed infiltration of the capsule with lymphocytes as did some of the glands in Bini's (1935) third case. Erythrophagocytosis was present in two of Bini's cases and in Levi's (1935) as in the present case. Plasma cells and eosinophilic leucocytes have been found in the cords and sinuses of the glands (Micheli and Gamna, 1928; Bini, 1935; Levi, 1935 and 1938).

The nature of the disease. The disease has been variously regarded as (1) a form of tuberculous rheumatism, (2) a type of rheumatic fever, (3) an endocrine disorder, (4) a form of rheumatoid arthritis, or (5) an independent disease. The evidence in favour of each view will be briefly discussed.

Tuberculosis. Edsall (1904) injected old tuberculin in a boy of thirteen years suffering from 
Still's disease and produced a general reaction and a local reaction in the affected joints; he found tubercle-like bacilli in the axillary glands but there was no histological evidence of tuberculosis nor did an emulsion of the glands produce tuberculosis in guinea-pigs. In Cozzolino's (1913) patient, who had previously suffered from tuberculous dactylitis, the tuberculin test caused a reaction in the affected joints. These observations have been thought to show that Still's disease is a form of toxic polyarthritis similar to the tuberculous rheumatism described by Poncet (1901). According to Brav and Hench (1934) the existence of tuberculous rheumatism is still undecided. Parkes Weber (1905) and Cunliffe (1907) regarded their cases as tuberculous because of positive tuberculin skin reactions. Most other authors report a negative tuberculin reaction (Koeppe, 1912; Longo, 1917; Simonetti,
1930 ; Benedettelli, 1934; Bini, 1935; Oggioni and Toldo, 1935). No tubercle bacilli have been found in sputum (Longo, 1917; Oggioni and Toldo, 1935), blood cultures (Oggioni and Toldo, 1935) or pleural fluid (Benedettelli, 1934) or in the glands (Micheli and Gamna, 1928; Simonetti, 1930; Benedettelli, 1934), whilst none of the authors cited in the table found evidence of tuberculosis at necropsy. This evidence confirms the present findings and does not support the tuberculous etiology of Still's disease despite the occasional suggestive clinical features (Koeppe, 1912; Longo, 1917). Reitano (quoted by Levi, 1935), however, takes the view that Still's disease may be due to various causes, tuberculosis being one.

RHEUMATIC FEVER. Longo (1917) suggested that Still's disease may be a form of rheumatic fever since cardiac complications and subcutaneous

TABLE SHOWING CHANGES FOUND AT NECROPSY (EXCLUDING LYMPH GLANDS)

\begin{tabular}{|c|c|c|c|c|}
\hline Author & Joints & Spleen & Serous cavities & Heart \\
\hline Still (1897) & $\begin{array}{l}\text { Three cases examined. Capsule thick- } \\
\text { ened.- Hyperaemia of synovia. } \\
\text { Fibrous adhesions. Cartilage pitted } \\
\text { in one case. }\end{array}$ & $\begin{array}{l}\text { Enlarged in each } \\
\text { case. }\end{array}$ & $\begin{array}{l}\text { Each case. } \\
\text { 1. Adherent peri- } \\
\text { cardium. } \\
\text { 2. Pleural adhe- } \\
\text { sions. }\end{array}$ & - \\
\hline $\begin{array}{l}\text { Koeppe } \\
\text { (1912) }\end{array}$ & Capsule of knees slightly thickened. & Enlarged. & $\begin{array}{l}\text { Adherent } \\
\text { cardium. }\end{array}$ & - \\
\hline Iseke (1923) & - & Enlarged. & - & $\begin{array}{l}\text { Tricuspid endo- } \\
\text { carditis. }\end{array}$ \\
\hline Stoye (1926) & $\begin{array}{l}\text { Knee: chronic inflammation of synovia } \\
\text { and capsule. }\end{array}$ & $\begin{array}{l}\text { 1. Enlarged. } \\
\text { 2. Perisplenitis. }\end{array}$ & $\begin{array}{l}\text { Adherent } \\
\text { cardium. }\end{array}$ & $\begin{array}{l}\text { Sclerosis of pul- } \\
\text { monary valve. }\end{array}$ \\
\hline $\begin{array}{l}\text { Strauss } \\
\quad(1926)\end{array}$ & $\begin{array}{l}\text { 1. Capsule of knee and elbow: no } \\
\text { inflammatory change. } \\
\text { 2. Erosion of cartilage. } \\
\text { 3. Granulations in left elbow. }\end{array}$ & $\begin{array}{l}\text { 1. Enlarged. } \\
\text { 2. No fibrosis. } \\
\text { 3. Perisplenic } \\
\text { adhesions. }\end{array}$ & $\begin{array}{l}\text { 1. Peric a rdiu m } \\
\text { thickened. } \\
\text { 2. Pleural adhe- } \\
\text { sions. }\end{array}$ & - \\
\hline $\begin{array}{l}\text { Micheli and } \\
\text { Gamna } \\
(1928) \\
\text { Case } 2\end{array}$ & - & $\begin{array}{l}\text { 1. Enlarged. } \\
\text { 2. Atrophy of fol- } \\
\text { licles. } \\
\text { 3. Pulp-congested. } \\
\text { 4. Hyalinization } \\
\text { of walls of ar- } \\
\text { terioles. } \\
\text { 5. Haemosidero- } \\
\text { sis. }\end{array}$ & $\begin{array}{l}\text { 1. Adherent peri- } \\
\text { cardium. } \\
\text { 2. Pleural adhe- } \\
\text { sions. } \\
\text { 3. Peritoneal ad- } \\
\text { hesions. }\end{array}$ & - \\
\hline $\begin{array}{l}\text { Bini (1935) } \\
\quad \text { Case } 1\end{array}$ & - & Follicles enlarged. & $\begin{array}{l}\text { Pericardial adhe- } \\
\text { sions. }\end{array}$ & - \\
\hline $\begin{array}{l}\text { Bini (1935) } \\
\text { Case } 2\end{array}$ & Histologically normal. & Fibro-adénie. & Pericarditis. & Myocarditis. \\
\hline $\begin{array}{l}\text { Bini (1935) } \\
\text { Case } 3\end{array}$ & Histologically normal. & $\begin{array}{l}\text { 1. Amyloid in fol- } \\
\text { licles. } \\
\text { 2. Haemosidero- } \\
\text { sis. }\end{array}$ & Pericarditis. & Myocarditis. \\
\hline $\begin{array}{l}\text { Oggioni and } \\
\text { Toldo } \\
\text { (1935) } \\
\text { Case } 2\end{array}$ & $\begin{array}{l}\text { 1. Breaking up and notching of outer } \\
\text { layers of cartilage. } \\
\text { 2. Deeper: fatty and mucoid degenera- } \\
\text { tion with necrosis in places. } \\
\text { 3. No inflammation. }\end{array}$ & $\begin{array}{l}\text { 1. Fibro-adénie. } \\
\text { 2. Hyalinization } \\
\text { of walls of ar- } \\
\text { terioles. }\end{array}$ & 一 & - \\
\hline Levi (1935) & $\begin{array}{l}\text { Chronic inflammation of periarticular } \\
\text { connective tissue. }\end{array}$ & $\begin{array}{l}\text { Proliferation } \\
\text { endothelium of } \\
\text { follicular } \\
\text { terioles. }\end{array}$ & $\begin{array}{l}\text { 1. Adherent peri- } \\
\text { cardium. } \\
\text { 2. Pleural adhe- } \\
\text { sions. }\end{array}$ & - \\
\hline
\end{tabular}


nodules occur in both conditions. Whilst pericarditis is common in Still's disease, occurring in eleven of the cases listed in the table, endocarditis is less frequent, being reported at necropsy only by Iseke (1923) and Stoye (1926). There is no necropsy report of mitral or aortic endocarditis though Parkes Weber $(1903,1905)$ and Poynton (1907) each reported a case clinically with endocarditis, presumably of these valves. Bini (1935) found myocarditis in cases 2 and 3 but it did not appear to be rheumatic. Longo (1917) found subcutaneous nodules in his first case but it is possible that this should be classed as Jaccoud's arthritis rather than Still's.

There is no report of Aschoff's nodules being found in the heart or joints in Still's disease. Fahr $(1921,1930)$ maintains that these must be present to make a diagnosis of rheumatic granulomatosis, but Young and McMahon (1935) pointed out that these nodules are not permanent structures so that when healing occurs only non-specific scars may be found. Thus there is no definite evidence in favour of the rheumatic hypothesis.

ENDOCRINE DISORDER. Bini (1935) examined the endocrine glands of three cases of Still's disease at necropsy, but found no abnormality although the possibility of there being some endocrine disorder is suggested by the frequent occurrence of exophthalmos (Still, 1897; Reimold and Stoeber, 1925; Koeppe, 1912) and the increase in blood calcium in some forms of infantile arthritis (Grenet and Casalis, 1934).

RheumatoID ARTHRITIS. The morbid anatomy of the joints in Still's disease as at present known is not sufficiently defined to differentiate it from that of rheumatoid arthritis of adults (e.g. see description of Young and McMahon, 1935). Hence it might be supposed that the diseases are the same and that the adenopathy and splenomegaly are merely additional features peculiar to childhood and which occasionally occur in adults (Strauss, 1926). Still (1897), however, pointed out that even advanced cases showed no bony changes whereas these occur early in rheumatoid arthritis, and that there occurs in children a disease in every clinical respect like rheumatoid arthritis in adults. He concluded that the two conditions are distinct entities.

AN INDEPENDENT DISEASE. The widespread enlargement of the glands, the fibro-adénie of the spleen and the multiple arthritis indicate that Still's disease is a generalized disorder. The glandular changes are consistent with its being infective in nature, which is in keeping with the inflammatory and degenerative changes in the joints. However, there is no reason to suppose it is a form of tuberculosis or rheumatic fever. Although differentiation from rheumatoid arthritis is less certain it is probable that Still's disease is an independent entity of unknown but probably infective etiology. Micheli and Gamna (1928), Simonetti (1930) and Levi (1938) take a similar view.

\section{Summary}

1. A case of Still's disease is described.

2. The anatomical changes in the joints and glands are discussed.

3. A summary of the morbid anatomical changes described in the literature of Still's disease is presented.

4. The nature of the disease is discussed and it is concluded that it is not a form of tuberculosis, rheumatic fever or an endocrine disorder but an independent type of arthritis of infective origin.

Thanks are due to Dr. C. Paget Lapage for permission to publish this case, Professor S. L. Baker for helpful advice and criticism and Dr. R. Whitehead for assistance with the Italian texts.

\section{REFERENCES}

Benedettelli, E. (1934). Pediatria, 42, 159.

Bini, G. (1935). Ibid., 13, 15.

Bloom, W. (1943). Maximow, A. A., and Bloom, W. A textbook of histology, Phila., p. 120.

Brav, E. A., and Hench, P. S. (1934). J. Bone Jt. Surg., 16,839 .

Cozzolino, O. (1913). Pediatria, 21, 401.

Cunliffe, E. N. (1907). Med. Chron., 4S., 14, 453.

Edsall, D. L. (1904). Arch. Pediat., 21, 175.

Fahr, T. (1921). Virchows Arch., 232, 134.

- (1930). Beitr. path. Anat., 85, 445.

Grenet, H., and Casalis, G. (1934). Revue du Rheumatisme, 1, 380.

Iseke, G. (1923). Z. Kinderheilk., 35, 314.

Koeppe, H. (1912). Jb. Kinderheilk., 76, 707.

Lang, F. J. (1935). Downey, H. A handbook of haematology, New York, 3, 2105.

Levi, S. (1935). Riv. Clin. pediat., 33, 1214. (1938). Ibid., 36, 409 .

Longo, A. (1917). Ibid., 15, 225.

Maximow, A. A. (1907). Beitr. path. Anat., 41, 122.

Micheli, F., and Gamna, C. (1928). Minerva med., Torino, 8, 6, 49.

Oggioni, G., and Toldo, L. (1935). Arch. ital. Pediat. Puer., 3, 461 .

Parkes Weber, F. (1903). Brit. med. J., 1, 730. (1905). Brit. J. Child. Dis., 2, 208.

Poncet, A. (1901). Gaz. Hôp., Paris, 74, 817.

Poynton, F. J. (1907). Edinb. med. J., N.S. 22, 226.

Reimold, W., and Stoeber, T. (1925). Mschr. Kinderheilk., 31, 597 .

Robb-Smith, A. H. T. (1938). J. Path. Bact., 47, 457.

Simonetti, R. (1930). Riv. Clin. pediat., 28, 22.

Still, G. F. (1897). Med.-chir. Trans. Lond., 80, 47.

Stoye, W. (1926). Z. Kinderheilk., 41, 528.

Strauss, H. (1926). Med. Klinik, 22, 1247.

Young, A. G., and McMahon, H. E. (1935). J. Bone Jt. Surg., 17, 151. 